\title{
Simulation of Pressurized Water Reactor to Find the Best Control Solution
}

\author{
Taia Petik*, Viktoriia Vataman, Konstantin Beglov \\ Odessa Polytechnic State University, 1 Taras Shevchenko Avenue, Odessa, 65044, Ukraine
}

Received: October 29, 2021. Revised: November 18, 2021. Accepted: December 17, 2021.

(C) 2021 The authors. Published by Lviv Polytechnic National University.

\begin{abstract}
Since it is impossible to simultaneously control all technological and thermal parameters of the nuclear reactor, a vertically distributed model of a power unit was developed, which allows determining the axial offset and analyzing the behavior of thermal and neutron-physical processes of individual zones in core during boron control and movement of rods, as well as regulating the power of the nuclear reactor. For ten vertically distributed zones, neutrons and thermal processes in the reactor core were analyzed, as was the change of the axial offset during the discharge of the reactor load under the influence of the movement of the rods and the increase in the boric acid concentration. The purpose of this publication is to develop a vertically distributed model of the facility and use information technology to find the best solution for the control of a pressurized water reactor.
\end{abstract}

Keywords: vertically distributed model; pressurized water reactor; axial offset; concentration of boron and xenon.

\section{Introduction}

With the help of a pressurized water reactor, a significant part of electricity is generated and operated in the nuclear power unit stabilization mode, but the discrepancy between electricity generation and consumption during the daily cycle is currently an urgent problem of power unit maneuvering. When changing the reactor power, it is necessary to simultaneously control the rapid change of many neutron-physical and technological parameters, which leads to the need to upgrade existing nuclear power plant (NPP) units by creating a system of automatic power control of the unit in maneuvering modes. A vertically distributed model of a pressurized water reactor (PWR) with relative state variables, which in a number of vertically distributed zones describe the neutron kinetics of the reactor, the gradual heat release, thermal processes in the fuel, shells and coolant, changes in xenon and boron concentrations, which can be used to calculate the axial offset (AO), has been developed in the form of systems of differential equations. The vertically distributed model of the pressurized water reactor is investigated when the load of the reactor is relieved when the rods are moving and the concentration of boric acid increases. Due to the vertically distributed model of the PWR, the parameters of neutron power regulators are optimized when controlling the reactor with absorbing rods and boric acid [1]-[2].

\section{Mathematical structure of the model}

The multipoint structure of the reactor model, which is known from [1]-[4], was chosen as the initial one. This multipoint mathematical model of PWR is divided by the height of the reactor core into 10 zones in order to:

- minimize modeling error associated with piecewise linear linearization of a nonlinear object;

- be able to implement in the simulation environment.

"Corresponding author. Email address: taiapetik@gmail.com

This paper should be cited as: T. Petik, V. Vataman, K. Beglov. Simulation of pressurized water reactor to find the best control solution. Energy Engineering and Control Systems, 2021, Vol. 7, No. 2, pp. 126 - 135. https://doi.org/10.23939/jeecs2021.02.126 
This multilayer structure of the reactor model is shown in Fig.1. Structurally, each zone consists of the following mathematical models-blocks: a point model of reactor kinetics, which connects the neutron flux density $\Phi$ with the reactivity $\rho$; model of energy release in fissile material, which binds the amount of energy $Q$ released as a result of fuel fission reactions; coolant heating model; heat transfer model inside the fuel rods, which relates the fuel temperature $t_{f}$ to the amount of released energy $Q$; model of the reactivity effect from xenon poisoning ${ }^{135} \mathrm{Xe}$; model of the temperature effect of reactivity; model of the effect of reactivity on power; model of the reactivity effect on the position of the regulatory group of regulators; model of the effect of reactivity on the concentration of boric acid in the coolant.

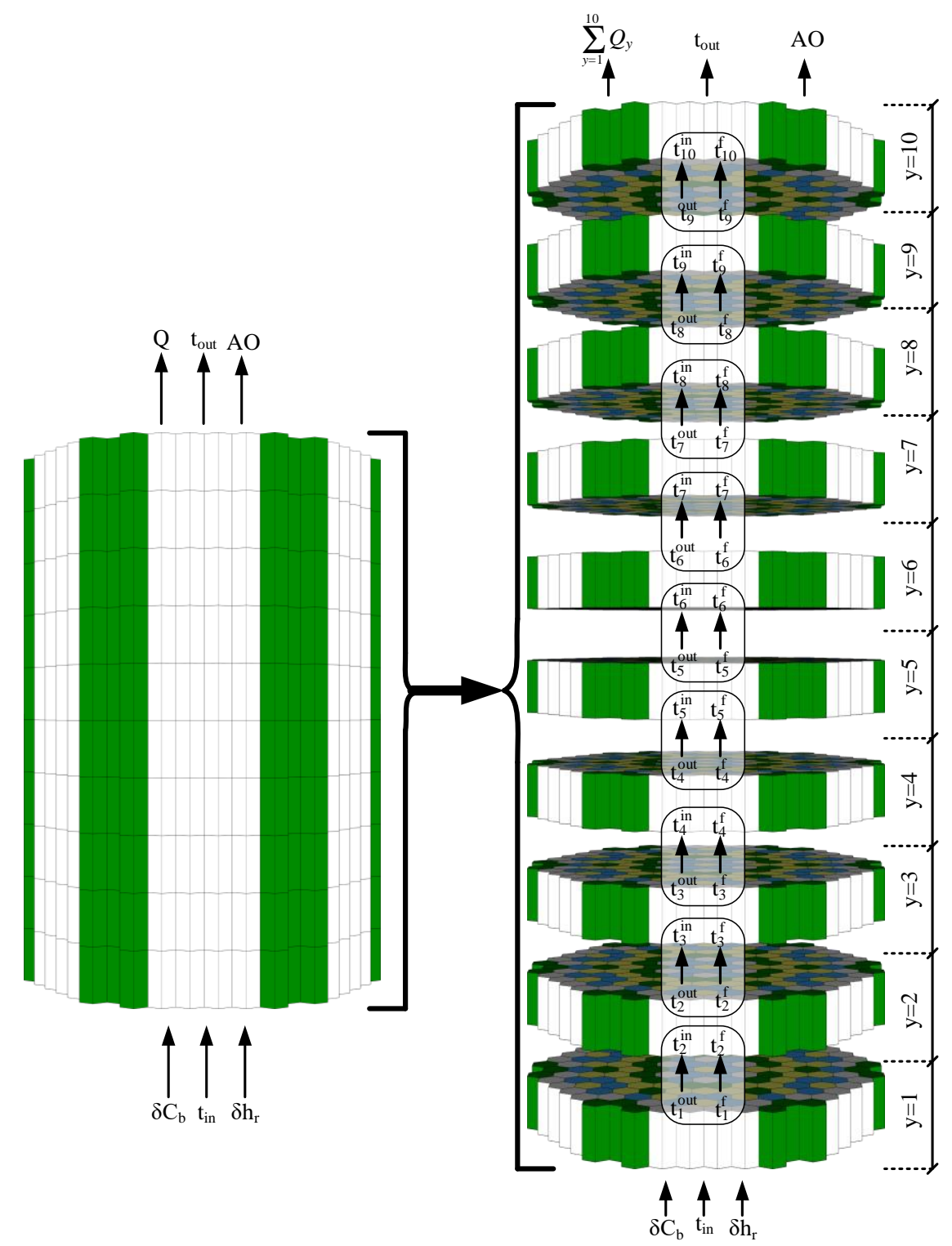

Fig.1. Multilayer nuclear reactor core structure with concentrated parameters in each layer.

Nuclear power unit with a pressurized water reactor from the standpoint of automatic control is an object with many complex dynamic processes with feedback and cross-links. To account for these relationships and processes, it is necessary to consider systems of differential equations in the mathematical model, including nonlinear [1].

The following assumptions are accepted in the paper. Each section of the nuclear reactor core in height should have no more than 6 segments of the entire cartogram, corresponding to $60^{\circ}$ symmetry. There remains one fuel assembly number 82 , which is not part of any of the 6 segments. It is accepted that each segment will have 4 sections, which make simulation of 4 groups of fuel assemblies, which are separated by operational years. Each segment of the core will have 4 characteristic areas of the groups of fuel assemblies and in Fig. 2 an example of such a division is given. 


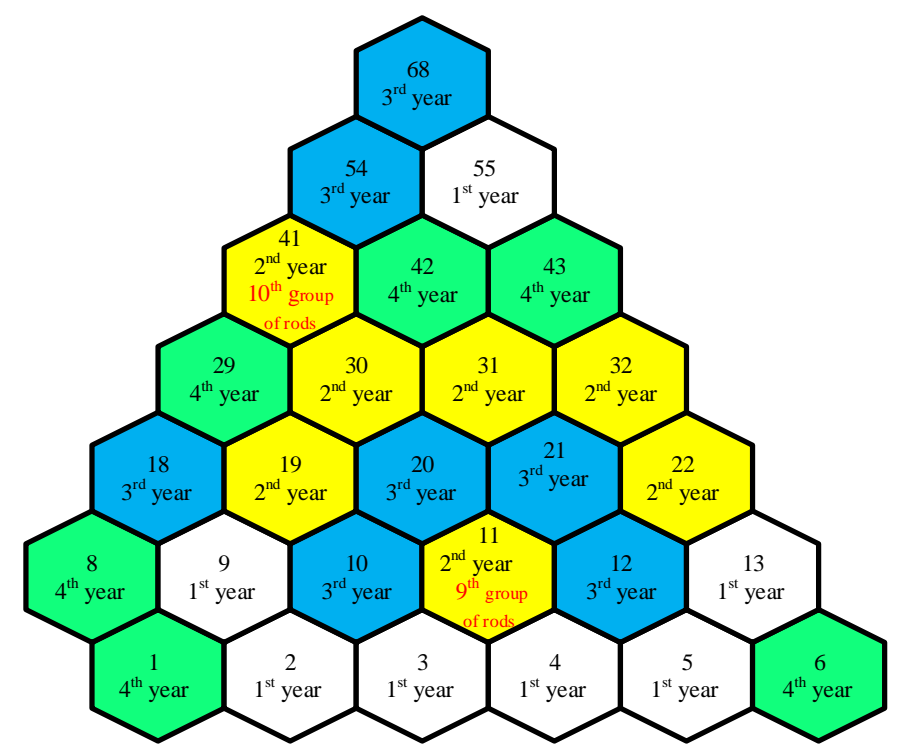

Fig.2. The diagram of 4 characteristic sections of groups of fuel assemblies in one of 6 segments: fuel assemblies of the first year (1 group) are marked in white, fuel assemblies of the second year ( 2 group) are marked in yellow, fuel assemblies of the third year (3 group) are marked in blue, fuel assemblies of the fourth year (group 4) are marked in green.

Thus, taking into account all the assumptions, such a multipoint model of the reactor is shown in Fig.3. considering all the above changes in the nuclear reactor core, mathematical model of the nuclear reactor core, which has the index $i$, as a reflection of the unit cell is proposed. Such a cell should include three indices, where the first

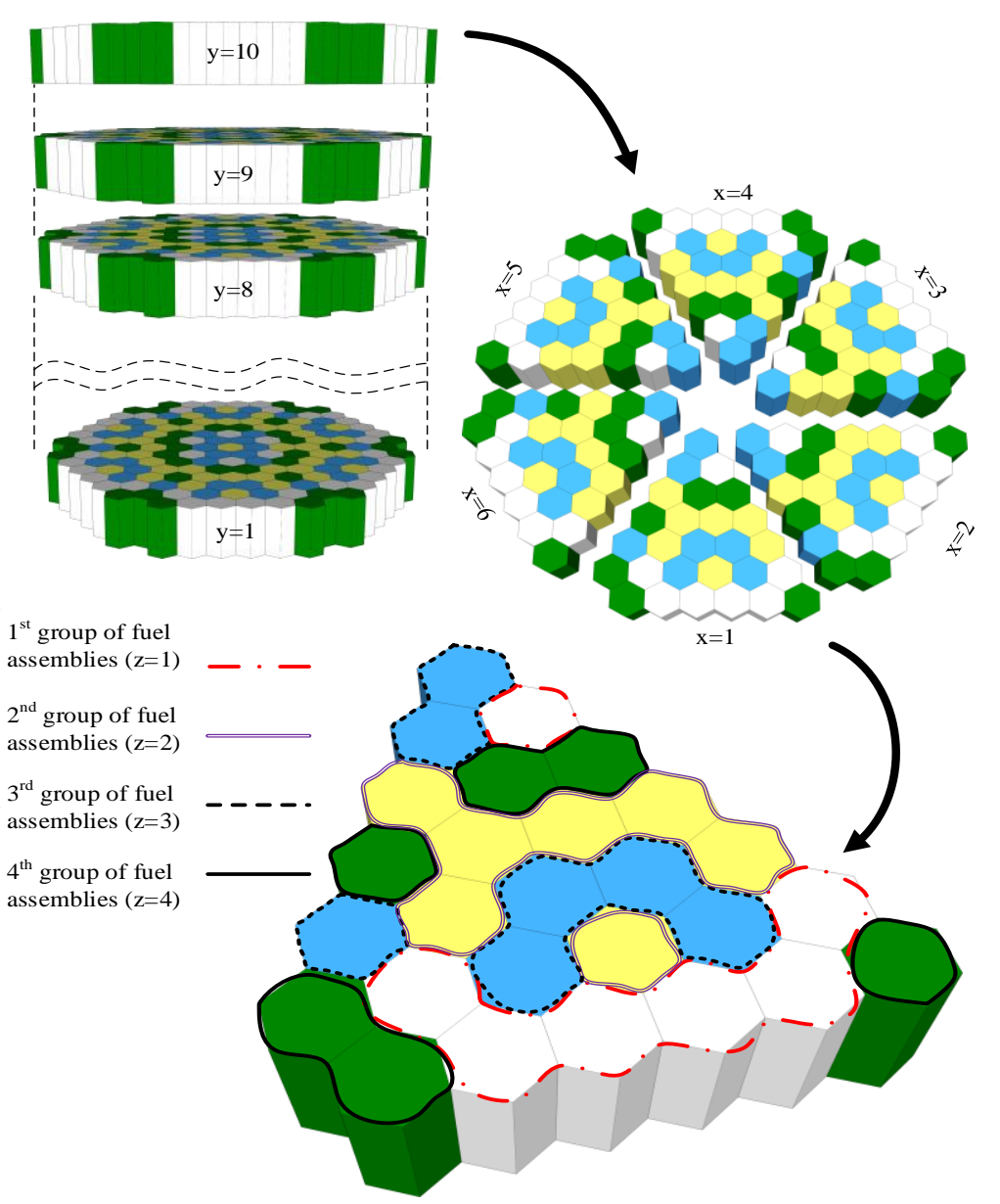

Fig.3. The diagram of the divided nuclear reactor core of the pressurized water reactor. 
index $y(1 \ldots 10)$ reflects the number of a certain layer of the nuclear reactor core in height; the second index $x(1 \ldots 6)$ displays the sector number of the $60^{\circ}$ segment symmetry of the nuclear reactor core; the third $z(1 \ldots 4)$ displays the section number of the fuel assembly group within the sector. This model of the reactor is written as $R\left(\delta \mathrm{C}_{b} ; t_{r, w, i n} ; \delta h ; i\right)=A O ; Q_{i}, t_{i, w, i n}$, which allows calculating the change in mentioned technological parameters.

\section{Distribution of parameters between sections of the nuclear reactor core}

Initially, a point mathematical model of the reactor was used for the calculation in general. This representation does not allow calculating the energy release by the height of the nuclear reactor core, which is a disadvantage of this model, because it is a quantitative measure of the stability of the reactor. The multipoint mathematical model [1] uses the division of the nuclear reactor core in height into 10 characteristic areas. This model uses the distribution of parameters only between the zones in height, as shown in Fig. 4.In the proposed mathematical model, the distribution of parameters occurs not only between the zones in height, but also between the $60^{\circ}$ segments symmetry, as well as between sections in the same segments. The distribution of parameters occurs on the lines of contact. In view of the above, the description of the distribution of parameters between fuel assemblies should be carried out only between the different years of firing of these fuel assemblies. In the current configuration, the redistribution of the required technological parameter $A_{x}$ will occur as the arithmetic mean between adjacent cells.

The above expressions are applied to the sector number of the $60^{\circ}$ segment symmetry of the nuclear reactor core $x$. There will be no differences between the sector numbers of the $60^{\circ}$ segment symmetry of the nuclear reactor core $x$, since they are all identical and almost completely repeat themselves.

The obtained expressions can be applied to other mathematical models of the reactor in order to determine the value of the required parameter in a specific unit cell, and, accordingly, in $y\left(\begin{array}{l}1 \\ \ldots\end{array} 10\right)$ number of the nuclear reactor core in height; $x(1 \ldots 6)$ sector number of the $60^{\circ}$ segment symmetry of the nuclear reactor core and finally $z(1 \ldots 4)$ serial number of the fuel assembly group within the sector.

\section{Mathematical model of reactor kinetics}

The application of perturbations to the reactor leads to a change in the neutron flux density. In this case, for each zone, the regularity of this change is described by a system that combines seven nonlinear differential equations of the first order, which take into account the six groups of delayed neutrons ${ }^{235} \mathrm{U}[3]$ :

$$
\left\{\begin{array}{c}
\frac{d \Phi}{d \tau}=\frac{\left(\rho(\tau)-\beta_{e f}\right) \cdot \Phi(\tau)}{l}+\sum_{j=1}^{6} \lambda_{j} \cdot C_{j}(\tau) \\
\frac{d C_{j}}{d \tau}=\frac{\beta_{j} \cdot \Phi(\tau)}{l}-\lambda_{j} \cdot C_{j}(\tau)
\end{array}\right.
$$

where $\Phi$ is the average neutron flux density, $\mathrm{cm}^{-2} \sec ^{-1} ; \rho(\tau)$ is reactor reactivity, in relative units.; $\beta_{e f}$ is the total average number of delayed neutrons, in relative units.; $\beta_{j}$ is the proportion of delayed neutrons of the $j$-th group, in relative units; $\lambda_{j}$ is the decay constant of the precursors of the $\mathrm{j}$-th nucleus-precursor of delayed neutrons, $\sec ^{-1} ; l$ is neutron lifetime, sec; $j$ is delayed neutron group number, $j=1 \ldots 6 ; C_{j}(\tau)$ is the effective concentration of precursor nuclei of delayed neutrons of the $j$-th group, $1 / \mathrm{cm}^{2} \cdot \mathrm{sec}$.

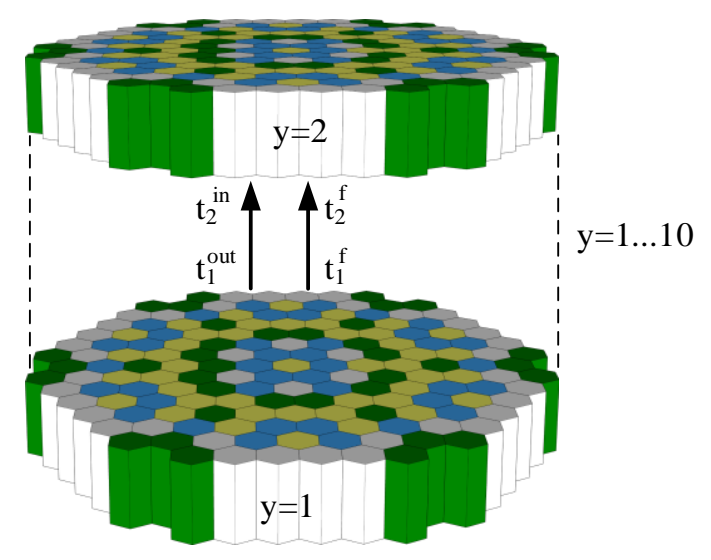

Fig.4. Distribution of parameters between the layers of the nuclear reactor core of the pressurized water reactor 
However, it is known that ${ }^{239} \mathrm{Pu}$ is formed in a nuclear reactor, which runs on natural or low-enriched uranium that contains mainly the isotope ${ }^{238} \mathrm{U}$, when capturing excess neutrons. During this, the following nuclear reactions take place:

$$
\begin{gathered}
{ }_{0}^{1} n+{ }_{92}^{238} \mathrm{U} \rightarrow{ }_{92}^{239} \mathrm{U} \rightarrow{ }_{93}^{239} \mathrm{~Np}+e^{-}+\bar{\nu}_{e}, \\
{ }_{93}^{239} \mathrm{~Np} \rightarrow{ }_{94}^{239} \mathrm{Pu}+e^{-}+\bar{\nu}_{e} .
\end{gathered}
$$

Therefore, the above-mentioned system of seven nonlinear first-order differential equations does not take into account the change in neutron flux density from the reactions of formation and fission of ${ }^{239} \mathrm{Pu}$ nuclei. To obtain a mathematical model of the kinetics of the reactions of formation and fission of ${ }^{239} \mathrm{Pu}$ nuclei, the above system of differential equations was used and such a system of equations remains unchanged except for other constants and the proportion of delayed neutrons of the $j$-th group. An updated system for changing the neutron flux density is proposed, which combines fourteen nonlinear differential equations of the first order, which include six groups of delayed neutrons ${ }^{235} \mathrm{U}$, and six groups of delayed neutrons ${ }^{239} \mathrm{Pu}$,and allows you to control the change in neutron flux density from the reactions of formation and fission of ${ }^{239} \mathrm{Pu}$ and ${ }^{235} \mathrm{U}$ nuclei.

The mathematical model of reactor kinetics, which allows taking into account the change in isotopic composition from the fission reaction not only from ${ }^{235} \mathrm{U}$ but also from ${ }^{239} \mathrm{Pu}$, which is formed in the core, is supplemented by differential equations:

$$
\begin{gathered}
\frac{d \Phi_{i, 5}}{d \tau}=\frac{\left(\rho(\tau)-\beta_{5}\right) \cdot \Phi_{i, 5}(\tau)}{l}+\sum_{j=1}^{6} \lambda_{j, 5} \cdot C_{i, j, 5}(\tau) ; \\
\frac{d C_{i, j, 5}}{d \tau}=\frac{\beta_{j, 5} \cdot \Phi_{i, 5}(\tau)}{l}-\lambda_{j, 5} \cdot C_{i, j, 5}(\tau) ; \\
\frac{d \Phi_{i, 9}}{d \tau}=\frac{\left(\rho(\tau)-\beta_{9}\right) \cdot \Phi_{i, 9}(\tau)}{l}+\sum_{j=1}^{6} \lambda_{i, j, 9} \cdot C_{i, j, 9}(\tau) ; \\
\frac{d C_{i, j, 9}}{d \tau}=\frac{\beta_{j, 9} \cdot \Phi_{i, 9}(\tau)}{l}-\lambda_{j, 9} \cdot C_{i, j, 9}(\tau),
\end{gathered}
$$

where $\Phi_{i}=\Phi_{i, 5}+\Phi_{i, 9}$ is the total average neutron flux density in the unit cell of the nuclear reactor core, $\mathrm{cm}^{-2} \mathrm{sec}^{-1}$; $\Phi_{i, 5}, \Phi_{i, 9}$ are the average neutron flux densities, respectively, for ${ }^{235} \mathrm{U},{ }^{239} \mathrm{Pu}, \mathrm{cm}^{-2} \mathrm{sec}^{-1} ; \rho(\tau)$ is the reactivity of the reactor, in relative units; $\beta_{5}, \beta_{9}$ are the total delayed neutrons fractions, respectively, for ${ }^{235} \mathrm{U}$ and ${ }^{239} \mathrm{Pu}$; $l$ is neutron lifetime, sec; $\lambda_{j, 5}, \lambda_{j, 5}$ are decay constants of the neutron precursor nuclei precursors, respectively, for delayed ${ }^{235} \mathrm{U}$ and ${ }^{239} \mathrm{Pu}, \sec ^{-1} ; C_{i, j, 5}(\tau), C_{i, j, 9}(\tau)$ are effective concentrations of delayed neutron precursor nuclei of the j-th group, for ${ }^{235} \mathrm{U}$ and ${ }^{239} \mathrm{Pu}$, respectively, in the unit cell of the nuclear reactor core, $1 / \mathrm{cm}^{2} \cdot \sec ; \beta_{j, 5}, \beta_{j, 9}$ are the fractions of delayed neutrons of the $j$-th group, respectively, for ${ }^{235} \mathrm{U}$ and ${ }^{239} \mathrm{Pu}$. The formation of ${ }^{239} \mathrm{Pu}$ from ${ }^{238} \mathrm{U}$ is described by the following system of differential equations:

$$
\left\{\begin{array}{l}
\frac{d N_{i, 8}}{d \tau}=-N_{i, 8} \cdot \sigma_{f, 8} \cdot \Phi_{i}-N_{i, 8} \cdot \sigma_{c, 8} \cdot \Phi_{i} \\
\frac{d N_{i, U-9}}{d \tau}=N_{i, 8} \cdot \sigma_{c, 8} \cdot \Phi_{i}-\lambda_{U-9} \cdot N_{i, U-9} \\
\frac{d N_{i, N p}}{d \tau}=\lambda_{U-9} \cdot N_{i, U-9}-\lambda_{N p} \cdot N_{i, N p} \\
\frac{d N_{i, 9}}{d \tau}=\lambda_{N p} \cdot N_{i, N p}-N_{i, 9} \cdot \sigma_{f, 9} \cdot \Phi_{i}-N_{i, 9} \cdot \sigma_{c, 9} \cdot \Phi_{i}
\end{array}\right.
$$

where $N_{i, 8}, N_{i, U-9}, N_{i, N p}, N_{i, 9}$ are the average atomic concentrations, respectively, ${ }^{238} \mathrm{U},{ }^{239} \mathrm{U},{ }^{239} \mathrm{~Np}^{\text {and }}{ }^{239} \mathrm{Pu}, \mathrm{cm}^{-3}$; $\sigma_{f, 8}, \sigma_{f, 9}$ are microscopic cross sections of the reaction of separation, respectively, for ${ }^{238} \mathrm{U},{ }^{239} \mathrm{Pu},{ }^{10^{-24}} \mathrm{~cm}^{2}$; $\sigma_{c, 8}, \sigma_{c, 9}$ are microscopic cross sections of radiation capture, respectively, for ${ }^{238} \mathrm{U},{ }^{239} \mathrm{Pu}, 10^{-24} \mathrm{~cm}^{2} ; \lambda_{U-9}, \lambda_{N p}$ are radioactive decay constants, respectively for ${ }^{235} \mathrm{U}_{\text {and }}{ }^{239} \mathrm{Pu}, \mathrm{sec}^{-1}$. 
Differential equations of ${ }^{135} \mathrm{Xe}$ operating speed at ${ }^{235} \mathrm{U}$ and ${ }^{239} \mathrm{Pu}$ distribution reused, which are presented as:

$$
\begin{gathered}
\frac{d N_{i, I, 5}}{d \tau}=P_{I, 5} \cdot \Phi_{i} \cdot \sigma_{f, 5} \cdot N_{i, 5}-\lambda_{I} \cdot N_{i, I, 5} \\
\frac{d N_{i, X e, 5}}{d \tau}=\lambda_{I} \cdot N_{i, I, 5}-\lambda_{X e} \cdot N_{i, X e, 5}-\Phi_{i} \cdot \sigma_{a, X e} \cdot N_{i, X e, 5} \\
\frac{d N_{i, I, 9}}{d \tau}=P_{I, 9} \cdot \Phi_{i} \cdot \sigma_{f, 9} \cdot N_{i, 9}-\lambda_{I} \cdot N_{i, I, 9} \\
\frac{d N_{i, X e, 9}}{d \tau}=P_{X e, 9} \cdot \Phi_{i} \cdot \sigma_{f, 9} \cdot N_{i, 9}+\lambda_{I} \cdot N_{i, I, 9}-\lambda_{X e} \cdot N_{i, X e, 9}-\Phi_{i} \cdot \sigma_{a, X e} \cdot N_{i, X e, 9},
\end{gathered}
$$

where $N_{i, I, 5}, d N_{i, I, 9}$ are the average atomic concentrations of ${ }^{135} \mathrm{I}$ in the fission reaction, respectively, for ${ }^{235} \mathrm{U}$ and ${ }^{239} \mathrm{Pu}, \mathrm{cm}^{-3} ; N_{i, X e, 5}, N_{i, X e, 9}$ are the average atomic concentrations of ${ }^{135} \mathrm{Xe}$ in the fission reaction, respectively, for ${ }^{235} \mathrm{U}$ and ${ }^{239} \mathrm{Pu}, \mathrm{cm}^{-3} ; P_{I, 5}, P_{I, 9}$ are the probabilities of ${ }^{135} \mathrm{I}$ formation during the fission reaction, respectively, for ${ }^{238} \mathrm{U}$ and ${ }^{239} \mathrm{Pu} ; P_{X e, 5}, P_{X e, 9}$ are the probabilities of ${ }^{135} \mathrm{Xe}$ formation during the fission reaction, respectively, for ${ }^{235} \mathrm{U}$ and ${ }^{239} \mathrm{Pu}$, $\mathrm{cm}^{-3} ; \sigma_{a, X e}, \sigma_{f, 5}$ are microscopic absorption and separation cross sections, respectively, for ${ }^{135} \mathrm{Xe}$ and ${ }^{235} \mathrm{U}, \mathrm{cm}^{2}$; $N_{i, 5}$ is the average atomic concentration of ${ }^{235} \mathrm{U}, \mathrm{cm}^{2} ; \lambda_{I}, \lambda_{X e}$ are the radioactive decay constants, respectively, for ${ }^{135} \mathrm{I},{ }^{135} \mathrm{Xe}, \mathrm{sec}^{-1}$.

\section{Mathematical model of energy release}

The fission of fuel nuclei during the operation of the reactor causes the release of heat. The introduction of the main share of thermal energy is provided by the kinetic energy of fission fragments (85 \%). There is an almost instantaneous conversion of this energy into heat. At the same time, this process is accompanied by the release of energy, which is associated with radiation $(0.7 \%)$. The deceleration of fission neutrons is accompanied by the release of about $2.6 \%$ of thermal energy.

It was decided to use the model of energy release, which uses the following equation to calculate the energy release of the nuclear reactor core:

$$
Q_{i}(\tau)=\Phi_{i}(\tau) \cdot V_{i} \cdot \Sigma_{f} \cdot E_{f}
$$

where $V_{i}$ is the volume of the unit cell of the core, $\mathrm{cm}^{3} ; \Sigma_{f}$ is macroscopic cross section, $\mathrm{cm}^{-1} ; E_{f}$ is fission energy of one nucleus, $\mathrm{J}$.

However, this expression included only the energy release of ${ }^{235} \mathrm{U}$ decay in the core of the nuclear reactor core. To calculate the energy release in the nuclear reactor core during the decay of ${ }^{239} \mathrm{Pu}$, the above equation was used with other coefficients of the equation. The mathematical model of energy release taking into account energy release both at fission of ${ }^{235} \mathrm{U}$ and ${ }^{239} \mathrm{Pu}$ nuclei is received:

$$
Q_{i}(\tau)=\Phi_{i}(\tau) \cdot V_{i} \cdot\left(\sum_{f, 5} \cdot E_{f, 5}+\Sigma_{f, 9} \cdot E_{f, 9}\right)
$$

where $\Sigma_{f, 5}, \Sigma_{f, 9}$ are macroscopic cross sections, respectively, for ${ }^{235} \mathrm{U}$ and ${ }^{239} \mathrm{Pu} \mathrm{cm}{ }^{-1} ; E_{f, 5}, E_{f, 9}$ are fission energy of one nucleus, respectively, for ${ }^{235} \mathrm{U}$ and ${ }^{239} \mathrm{Pu}, \mathrm{J}$.

\section{Mathematical model of energy transfer to fuel and coolant}

In paper [1], the equation of heat balance for fuel rods of the nuclear reactor core is proposed. However, applying the division of the nuclear reactor core into layers by height, sectors of the segment of $60{ }^{\circ}$ symmetry and sections of the group of fuel assemblies within the sector, the equation takes the below form:

$$
\begin{gathered}
Q_{i}(\tau)=c_{p, f} \cdot m_{i, f} \cdot \frac{d t_{i, f}}{d \tau}+\alpha \cdot F_{i}\left(t_{i, f}-t_{i, w}\right) \\
\alpha \cdot F_{i}\left(t_{i, f}-t_{i, w}\right)=c_{p, w} \cdot m_{i, w} \cdot \frac{d t_{i, w}}{d \tau}+\frac{2 \cdot c_{p, w} \cdot m_{i, w}}{\tau_{0}} \cdot\left(t_{i, w}-t_{i, w, i n}\right),
\end{gathered}
$$


where $c_{p, f}, c_{p, w}$ are specific heat capacities, respectively, of fuel and coolant, $\mathrm{J} /(\mathrm{kg} \cdot \mathrm{K}) ; m_{i, f}, m_{i, w}$ are masses, respectively, of fuel and coolant, $\mathrm{kg} ; t_{i, f}, t_{i, w}$ are temperatures of fuel and coolant, respectively, ${ }^{\circ} \mathrm{C} ; t_{i, w, i n}$ is coolant temperature at the inlet, ${ }^{\circ} \mathrm{C} ; \alpha$ is heat transfer coefficient from the surface of the fuel rods to the coolant, $\mathrm{W} /\left(\mathrm{m}^{2} \cdot \mathrm{K}\right)$; $F_{i}$ is the surface area of the fuel rods that transfers heat, $\mathrm{m}^{2} ; \tau_{0}$ is the time of passage of the coolant through the cell of the nuclear reactor core, sec.

\section{Mathematical model of reactivity effects}

Perturbation of the reactivity of the nuclear reactor core consists of the sum of the effects [6]:

$$
\delta \rho_{i}=\delta \rho_{i, r}+\delta \rho_{i, b}+\delta \rho_{i, N}+\delta \rho_{i, X e}+\delta \rho_{i, t}
$$

where $\delta \rho_{i, r}, \delta \rho_{i, b}, \delta \rho_{i, N}, \delta \rho_{i, X e}, \delta \rho_{i, t}$ are the reactivity effects introduced, respectively, by the regulatory group of organs of adjusting of control and protect system, the concentration of boric acid in the coolant of the primary circuit, the change in reactor power, the concentration of toxins in the fuel, the change in temperature of the coolant of the primary circuit.

To calculate the reactivity introduced by the regulating group of organs of adjusting of control and protect system, the following equation was used:

$$
\delta \rho_{i, r}=\frac{\partial \rho_{i}}{\partial h_{i, r}} \delta h_{i, r}
$$

where $\frac{\partial \rho_{i}}{\partial h_{i, r}}$ is coefficient of reactivity from the position of adjusting organs; $\delta h_{i, r}$ is deviation of the position of adjusting organs.

To calculate the effect of reactivity, which was introduced by changing the concentration of boric acid in the coolant of the primary circuit, the equation was used:

$$
\delta \rho_{i, b}=\frac{\partial \rho_{i}}{\partial C_{i, b}} \delta C_{i, b}
$$

where $\frac{\partial \rho_{i}}{\partial C_{i, b}}$ is reactivity coefficient from the concentration of boric acid; $\delta C_{i, b}$ is deviation of boric acid concentration.

The effect of reactivity from changes in reactor power [3], [4] is as follows:

$$
\delta \rho_{i, N}=\frac{\partial \rho_{i}}{\partial N} \delta N
$$

where $\frac{\partial \rho_{i}}{\partial N}$ is reactivity coefficient of reactor power; $\delta N$ is deviation of reactor power.

The change in reactivity as a result of poisoning of the nuclear reactor core with xenon is defined as:

$$
\delta \rho_{i, X e}=\frac{\partial \rho}{\partial N_{X e}} \delta N_{i, X e},
$$

where $\frac{\partial \rho}{\partial N_{X e}}$ is reactivity coefficient of ${ }^{135} \mathrm{Xe}$ concentration; $\delta N_{i, X e}$ is deviation of ${ }^{135} \mathrm{Xe}$ concentration.

To calculate the effect of reactivity introduced by the change in coolant temperature [3], [4], the differential equation was used:

$$
\delta \rho_{i, t}=\frac{\partial \rho_{i}}{\partial t_{w}} \delta t_{i, w}
$$

where $\frac{\partial \rho_{i}}{\partial t_{w}}$ is the reactivity coefficient of the coolant temperature; $\delta t_{i, w}$ is deviation of coolant temperature. 


\section{Simulation model of the distributed core of the reactor}

Using equations (1)-(24), a simulation model was built, which allowed simulating the necessary processes associated with the nuclear reactor core. Figure 5, as an illustration, shows a diagram of a simulation model of one group of fuel assemblies of the symmetry sector within the symmetry sector and the height layer of the nuclear reactor core, which allows simulating a model of a nuclear power plant with a pressurized water reactor with a distributed reactor core.

The model of one group of fuel assemblies of the symmetry sector within the symmetry sector and the height layer of the core (see Fig. 5) consists of 21 differential equations, 3 input parameters $\left(\delta h, \delta \mathrm{C}_{i, b}, t_{i, w \text {,in }}\right)$ and 4 output parameters $\left(\Phi_{i}, Q_{i}, t_{i, w, \text { out }}, t_{i, f}\right)$. The behavior of the neutron field depends on the formed effects of reactivities, which are shown in Figure 5. These intrinsic effects of reactivity are able to change the thermal power without a control system, so it is especially important to control the change in such reactivities, because they affect the stability of the reactor in the transition from one power level to another [5]-[8].

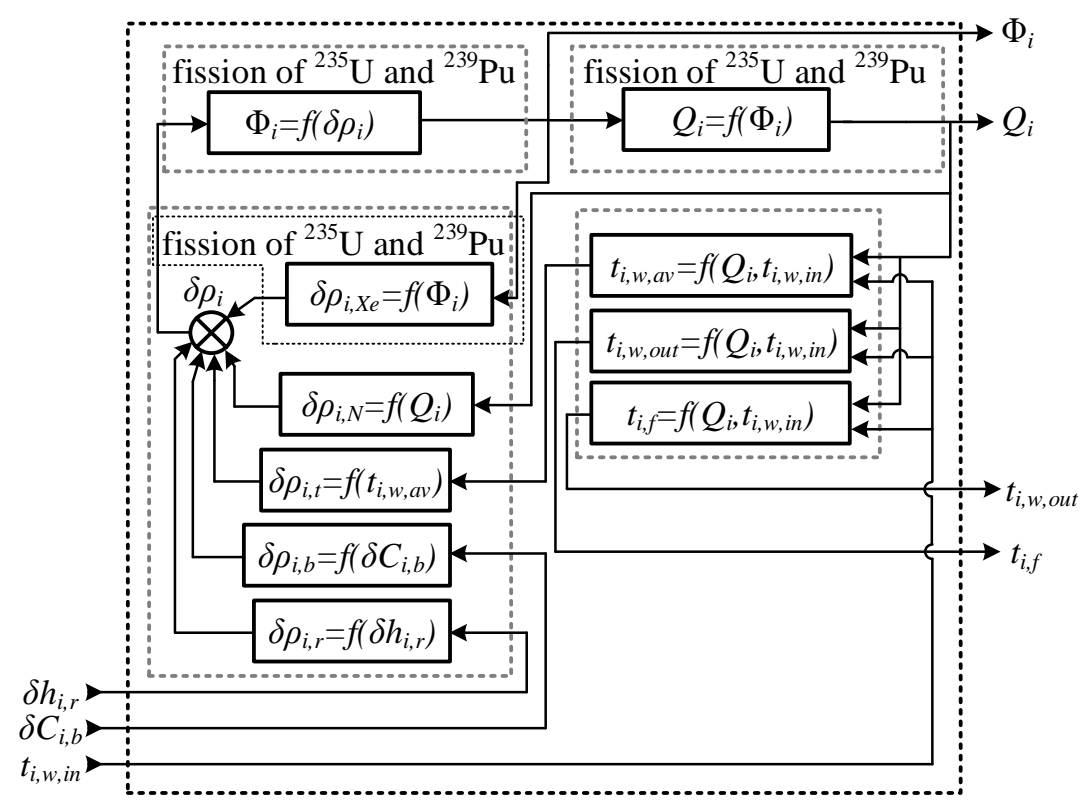

Fig.5. Scheme of the simulation model of the proposed unit cell

To calculate such initial parameters of the model as $A O, \Phi_{i}, Q_{i}, t_{i, w, o u t}, t_{i, f}$, the following equations are used:

$$
\begin{gathered}
A O=\frac{\left(\sum_{a=6}^{10} \sum_{b=1}^{6} \sum_{c=1}^{4}\left(Q_{y_{a}, x_{b}, z_{c}, \text { top }}\right)\right)-\left(\sum_{a=1}^{5} \sum_{b=1}^{6} \sum_{c=1}^{4}\left(Q_{y_{a}, x_{b}, z_{c}, \text { bot }}\right)\right)}{\left(\sum_{a=6}^{10} \sum_{b=1}^{6} \sum_{c=1}^{4}\left(Q_{y_{a}, x_{b}, z_{c}, \text { top }}\right)\right)+\left(\sum_{a=1}^{5} \sum_{b=1}^{6} \sum_{c=1}^{4}\left(Q_{y_{a}, x_{b}, z_{c}, \text { bot }}\right)\right)} \cdot 100 \% \\
\Phi_{i}=\sum_{a=1}^{10} \sum_{b=1}^{6} \sum_{c=1}^{4}\left(\Phi_{y_{a}, x_{b}, z_{c}}\right) \\
Q_{i}=\sum_{a=1}^{10} \sum_{b=1}^{6} \sum_{c=1}^{4}\left(Q_{y_{a}, x_{b}, z_{c}}\right) \\
t_{i, w, o u t}=\frac{\sum_{y=6}^{10} \sum_{x=1}^{6} \sum_{z=1}^{4}\left(t_{y, x, z, w, o u t}\right)}{\left(\sum_{y=10}^{10} y\right)+\left(\sum_{x=1}^{6} x\right)+\left(\sum_{z=1}^{4} z\right)} \\
t_{i, f}=\frac{\sum_{y=6}^{10} \sum_{x=1}^{6} \sum_{z=1}^{4}\left(t_{y, x, z, f}\right)}{\left(\sum_{y=10}^{10} y\right)+\left(\sum_{x=1}^{6} x\right)+\left(\sum_{z=1}^{4} z\right)}
\end{gathered}
$$




\section{Simulation results}

The results of the comparison of the change in the position of the regulating group of adjusting organs and the axial offset during the daily maneuver at the time of the simulation, which operates by the method of control with constant steam pressure in the second circuit, are shown in Fig.6 and Fig.7. In addition, the result of changes in the concentration of boric acid during the daily maneuver with two control methods is shown, which is presented in Fig.8. Fig.6, Fig.7 and Fig.8 show the following curves of modeling the daily maneuver: 1 - with a constant temperature of the coolant at the reactor inlet; 2 - with constant vapor pressure in the second circuit.

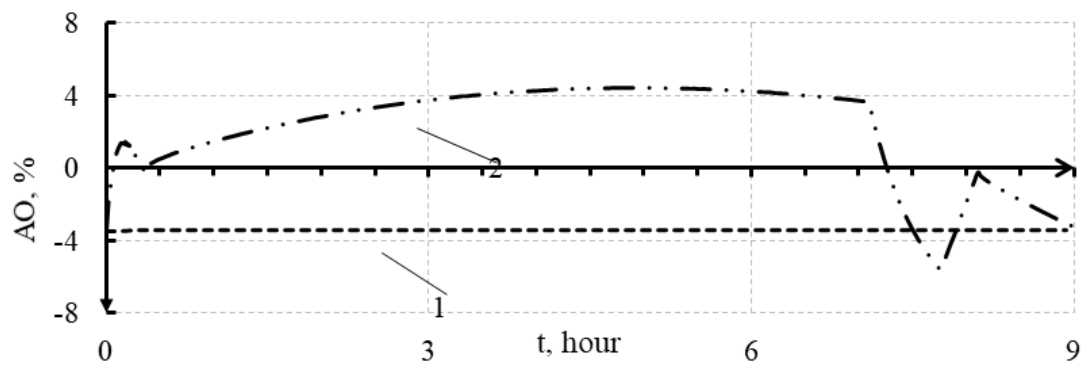

Fig.6. The result of changing the axial offset during the daily maneuver.

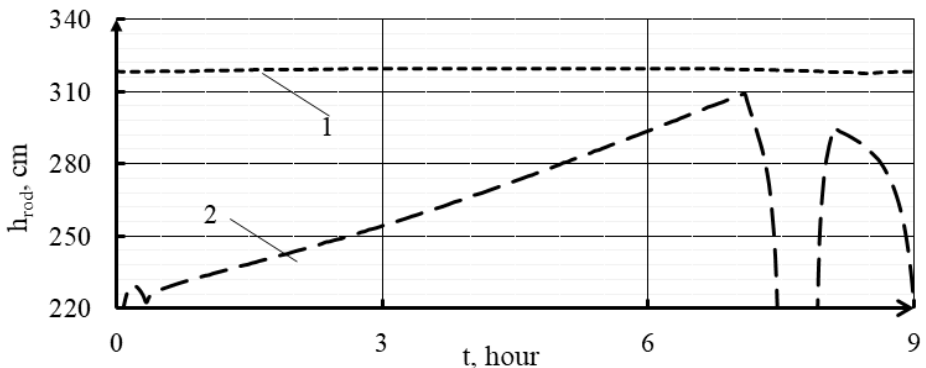

Fig.7. The result of changing the position of the regulatory group of adjusting organs during the daily maneuver.

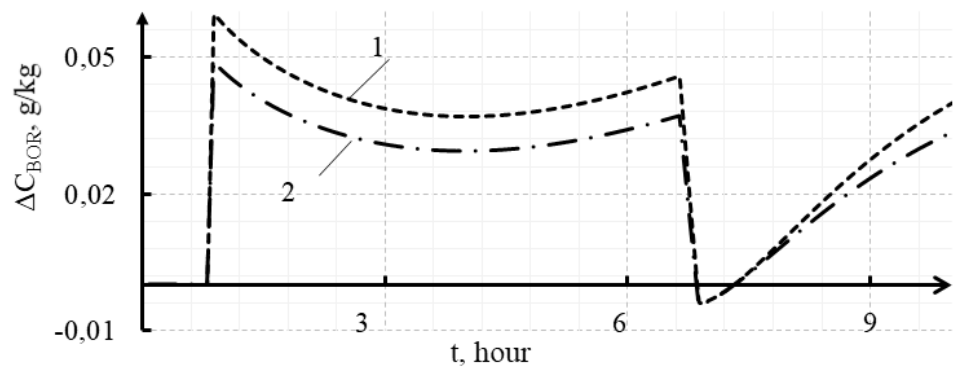

Fig.8. The result of changes in the concentration of boric acid during the daily maneuver

\section{Conclusion}

A vertically distributed model of a pressurized water reactor has been developed in the form of systems of differential equations with relative state variables that in a given number of vertically distributed zones describe the neutron kinetics of the reactor, gradual heat release, thermal processes in fuel, shells and coolants, changes in xenon and boron. Distributed mathematical model of the reactor, allows calculating the axial offset as a quantitative measure of a nuclear reactor. For ten vertically distributed zones the following are analyzed: neutrons and thermal processes in the reactor core, as well as the change of axial offset during the discharge of the reactor load under the influence of the movement of the rods and increasing the concentration of boric acid. 


\title{
References
}

[1] Maksymov M. V., Tsiselskaya T. A., Kokol E. A. Method for controlling a reactor plant with WWER-1000 in maneuverable mode. Problems of Control and Informatics: Intern. scientific and technical journal. -2015. -No. 3. - p. 59 - 75. (in Russian)

[2] Severin V. P., Nikulina E. N., Lyutenko D. A., Bobukh E. Y. The problem of maneuverability of a nuclear power unit and the development of models of its control systems. Bulletin of the National Tech. University "Kharkov Polytechnic Institute". Kharkov: NTU "KhPI", 2014. No. 61 (1103). p. 24 - 29.(in Russian)

[3] Verkhivker G. P., Kravchenko V. P. Fundamentals of calculation and design of nuclear power reactors / Ed. V. A. Dubkovsky. Odessa: TES, 2008. 409 pp. (in Russian)

[4] Ivanov V. A. Regulation of power units. L.: Mashinostroenie, 1982. 311 p. (in Russian)

[5] Borisenko V. I., Samoilenko D. V., Kadenko I. N. Peculiarities of some transient modes with load dropping on WWER-1000 // Atomic energy. T.115. Issue. 3. 2013. p. 132-136. (in Russian)

[6] Nikulina E. N., Severin V. P., Lukidova D. A. Mathematical models for the study of transient modes of the WWER-1000 nuclear reactor of the V-320 series, 2018. No.1(77). p. 18-23. (in Russian)

[7] Andryushenko S. A., Afrov A. M., Vasiliev B. Y., Generalov V. N., Kosourov K. B., Semchenko Y. M., Ukraintsev V. F. NPP with WWER-type reactors 1000 M.: Logos, 2010. 604 p. (in Russian)

[8] Nikulina E. N., Severin V. P. Synthesis of optimal automatic control systems for a power unit in normal operating conditions // Nuclear and radiation safety. - 2013. - No. 3 (59). - P. 62 - 68.(in Russian)

\section{Моделювання водо-водяного ядерного реактора для знаходження найкращого рішення з управління}

\author{
Тая Петік, Вікторія Ватаман, Костянтин Беглов
}

Державний університет «Одеська політехніка», проспект Тараса Шевченка, 1, Одеса, 65044, Україна

\section{Анотація}

Оскільки одночасно неможливо контролювати всі технологічні і теплові параметри роботи ядерного реактора, була розроблена вертикально розподілена модель управління ядерним реактором, що дозволяє визначити аксіальний офсет та проаналізувати поведінку теплових і нейтроно-фізичних процесів окремих зон активної зони при борному регулюванні і переміщені стрижнів, а також регулювати потужність ядерного реактора. Для десяти вертикально розподілених зон проаналізовані нейтроні і теплові процеси в активній зоні реактора, а також зміна аксіального офсету при скиданні навантаження реактора під впливом переміщення стрижнів та збільшення концентрації борної кислоти. Мета даної публікації полягає в розробці вертикально розподіленої моделі об’єкту та використанні інформаційної технології для знаходження найкращого рішення з управління водо-водяним енергетичним реактором.

Ключові слова: вертикально розподілена модель; водо-водяний енергетичний реактор; аксіальний офсет; концентрація бору і ксенону. 